\title{
Evaluation of Diabetes Mellitus bearer towards basic health care attention in Rio Grande do Norte
}

\author{
Avaliação do cuidado ao usuário portador de Diabetes Mellitus na Atenção \\ Básica de Saúde do Rio Grande do Norte
}

\begin{abstract}
Alcebíades José dos Santos Neto, Álison Wílian de Souza Pereira, Clístenes Stênio Lima de Medeiros, Marcos Antônio Costa Ferreira de Macêdo, Nilma Dias Leão Costa, José Vílton da Costa.
\end{abstract}

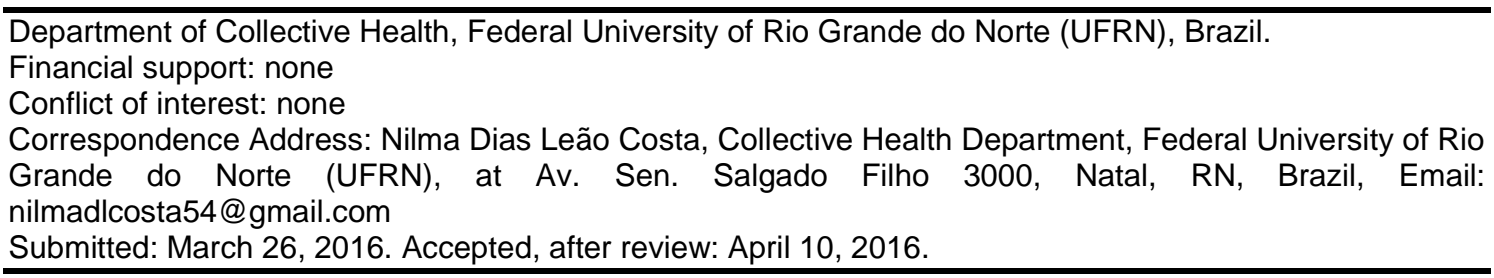

\begin{abstract}
Background/purpose: The Diabetes Mellitus (DM) is considered one of the main causes of death for non-communicable chronic diseases (NCCD) in the world, stating a considerable prevalence in Brazil as well. Therefore, the purpose of this study is to analyze the satisfaction of the DM patients taken care at public primary health system in the state of Rio Grande do Norte (RN), and also, to present the situation about the services offered to these patients. Methods: This is a descriptive study, using data from "External Evaluation Instrument of Access Improvement and Quality of Primary Care Program" (known as PMAQ-AB), regarding the state of $\mathrm{RN}$, as held from May to August of 2012, with a total of 119 attendees. Results: In accordance with the patients, the primary health care unity (PHCU) works on days and shifts correctly (84\%) and such timeframe comply with their needs (82\%), with an average of waiting time on about 31 minutes and rendering sufficient time with the doctor (89\%), although insuch appointment the patients don't have their feet examined $(82,4 \%)$ or receive proper advice about feet care $(63 \%)$. Only five users $(4,2 \%)$ needed to pay for medication and almost $80 \%$ have considered the health care provided as good or very good. Conclusion: The study evidenced the access to the PHCU and to medication, the reception, the physical infra-structure and satisfaction of the patients with the care provided as well evaluated. Although certain improvement is needed regarding the continuity of the treatment and thoroughly physical examination as carried out.
\end{abstract}

Key-words: Diabetes Mellitus; Primary health care; Health evaluation. 


\section{RESUMO}

Objetivos: A Diabetes Mellitus (DM) é considerada uma das principais causas de morte por Doenças Crônicas Não-Transmissíveis (DCNT) no mundo, possuindo prevalência considerável, também, no Brasil. Dessa forma, este estudo buscou analisar a satisfação do usuário portador da DM, atendido na Atenção Básica de Saúde do Rio Grande do Norte (RN), como também, apresentar a situação dos serviços oferecidos a esses pacientes. Métodos: Estudo descritivo, com dados do instrumento de Avaliação Externa do Programa de Melhoria do Acesso e da Qualidade da Atenção Básica (PMAQ-AB), referente ao $\mathrm{RN}$, realizado no período de maio a agosto de 2012, com um total de 119 participantes, que preencheram o critério de inclusão. Resultados: 0 estudo encontrou que, segundo os usuários, as unidades de saúde funcionam nos dias e turnos corretos (84\%) e este tempo atende suas necessidades (82\%), levando cerca de meia hora para serem atendidos e com tempo suficiente com o médico $(89 \%)$, apesar de, neste tempo, não terem os pés examinados $(82,4 \%)$ ou recebido aconselhamento sobre cuidados com o pé (63\%). Apenas cinco usuários $(4,2 \%)$ precisaram pagar por medicamentos e quase $80 \%$ consideraram o cuidado bom ou muito bom, com nota média de 8,35. Conclusões: $O$ estudo mostrou que o acesso à unidade de saúde e aos medicamentos, o acolhimento, as condições estruturais e a satisfação do usuário com o cuidado que lhes é oferecido foram bem avaliados. Porém, necessita-se de melhorias em relação à continuidade do tratamento do paciente diabético e exame físico minucioso.

Descritores: Diabetes Mellitus; Atenção Primária à Saúde; Avaliação em Saúde.

\section{INTRODUCTION}

The Non-Communicable Chronic Diseases (NCCD) are the leading causes of death worldwide, accounting for $63 \%$ of deaths in $2008^{1}$. It is noteworthy, by all means, the NCCDs are prone to occur with certain predominance on the low and middle income average countries ${ }^{2}$. From this perspective, such diseases began to lead the causes of death ranking Brazil, since the $80^{\prime} \mathrm{s}^{3}$. These NCCDs constitute to a real problem of greater magnitude of public health, since they are responsible for $72 \%$ of death causes, as the diabetes to render the main responsible roleon about $5.2 \%$ of such deaths, reaching a great deal on those who belong to vulnerable groups such as the elderly, low education literacy and income $e^{4}$. 
Occupying one of the four causes of death inured to NCCDs, it is estimated that diabetes mellitus, in 1995, had peaked around $4.5 \%$ of the world adult population and in a perspective of 2025 it is expected to reach the index of $5.4 \%$, and escalating in the number of cases in developing countries ${ }^{5}$. A multicenter population-based study conducted in $1988^{6}$, within nine state capitals had evidenced the prevalence of diabetes among the ages of 30-69 years old to reach $7.6 \%$, as the South and Southeast regions the place where there are the highest prevalence rates of diabetes mellitus.

The data of mortality from diabetes in the population in general, reveal the magnitude of such disease. According to the data of DATASUS ${ }^{7}$, Brazil, in 2011, had evidenced a mortality rate of 30.3 per each group of 100,000 inhabitants. In the Northeast, such figure shows a little higher rate if compared to the national mortality, reachingthe mortality around 36.9 per 100,000 inhabitants. In Rio Grande do Norte, the mortality rate reaches 43.7 per 100,000 inhabitants, a considerably higher number from the two previous data numbers.

The diabetes is a group of metabolic diseases featured by hyperglycemia and associated complications, disorders and failure of various organs, particularly eyes, kidneys, nerves, brain, heart and blood vessels. Such hyperglycemia may result from defects in secretion and/or the action of insulin, linking specific pathogenic processes, for instance: destruction of pancreatic beta cells, resistance to insulin action, insulin secretion disorders, among others ${ }^{8}$. It is a disease of well-defined diagnostic criteria, however inured from a complex treatment, onceits approach requires pharmacological treatment and changes in the patient's lifestyle ${ }^{9}$.

Due to the presence of high morbidity and mortality rates, the prevention of diabetes and its complications, to the date, is a public health priority. Upon such scenario, the primary care focuses on prevention of risk factors for diabetes, such as physical inactivity, obesity, unhealthy eating habits, identification and treatment of high-risk individuals for diabetes, thus constituting the primary prevention, which includes the National Program of Health Promotion (NPHP), created in 2006. As the secondary prevention focuses on identifying certain undiagnosed cases of diabetes for the proper treatment, in the meantime tertiary prevention intensifies the treatment of patients already diagnosed, focusing on 
preventing acute and chronic complications ${ }^{10}$. Additionally to these forms of prevention, the access assurance, the utilization of health care and the quality of the rendered service are essential in order to reduce diabetes complications ${ }^{11}$.

Regarding assistance quality, towards the access assurance and utilization of the health services, it can be highlighted a few studies. A study conducted in the Municipality of Francisco Morato (SP) ${ }^{12}$, as it assessed the quality of care in the following aspects: service utilization, quality of the appointment, lifestyle. The results showed a precarious access to health services, which is, among the 64 patients users of the Family Health Program (FHP), 17 (26.6\%) said they had no access to health services and betweenthe patients who had access, 25 (53.2\%) commuted to basic units or hospitals in other municipalities and only $15(31.9 \%)$ were treated at the local FHP. Another study, once conducted in Santos (SP) ${ }^{(13)}$ showed a distance between what is recommended in primary care services and what is actually rendered. It was found among patients diagnosed with diabetes $78.8 \%$ did not receive on a regular basis the visits from the Health Strategy Team (HST). It also pointed out that $90.7 \%$ of diabetic patients did not report any participation in educational groups, and $57.9 \%$ of those who handed over medicines were acquired in public health services.

Therefore, the key feature of such study is to render analysis towards the care attention and satisfaction of the user bearer of diabetes mellitus in regard to the basic health care attention in Rio Grande do Norte.

\section{METHODS}

"Programa de Melhoria do Acesso e da Qualidade da Atenção Básica" (PMAQ-AB)

\section{Access Improvement and Quality of Primary Care Program}

There had been a descriptive study using data from the PMAQ-AB External Evaluation Instrument, referring to the state of Rio Grande do Norte once carried out from May to August 2012, corresponding to the first program cycle ${ }^{14}$. 
The PMAQ-AB was established by the Ordinance No. 1,654 GM/MS, as of July $19^{\text {th }}, 2011$, and was the product of an important process of negotiation and agreement between three spheres of Brazilian public health care system (SUS) management, consisting of four phases: adhesion and contracting; development; external evaluation; contracting reassurance. The adhesion of the Primary Care Team (PCT) was performed voluntarily and became permanent out from such scope together with the municipal manager, the one entitled to formalize the adhesion of the municipality towards the ministry of health (MS), provided to submit proper compliance with the principles of primary health care. Afterwards, the participating units receive a financial incentive in order to stimulate their membership and retention to the program $^{14}$.

It is valuable to note the permanence of PCT in the program to be subject to the compliance of certain criteria, such as the monthly supply of the Primary Care Information System; not to be downgraded in more than one standard deviation throughout three months or more upon the score indicators; visual identification as defined by the Ministry of Health, containing such information as the services offered by the portfolio of the team, the working hours of the Basic Health Unit, the name and shift of professionals; among other criteria ${ }^{14}$.

As another phase of the program, the development, it consisted in the stage of development of the set of actions which would be undertaken by primary care teams, by municipal and state administrations and the Ministry of Health. At such stage it was organized into four dimensions: self-assessment, monitoring, permanent education and institutional support ${ }^{14}$.

The external evaluation instrument, once taken the third phase of the program, is organized into three modules. Module one refers to the observation in the health unit by the evaluator; Module two is accomplished through a row of interviews with health unit professionals and verification of documents; as per such study there will be analyzed the Module three; an interview with the user of the Basic Health Unit. The PMAQ-AB was funded by the Primary Care Department from Ministry of Health once applied in all municipalities in partnership with Superior Federal Education Institutions ${ }^{14}$.

Finally, the fourth phase of the program, the contracting reassurance, in charge to analyze the results of the external evaluation instrument and to perform 
a new set of contractual indicators and commitments, with the intention of trying to improve the unsatisfactory parameters and trying to keep the ones underway of adaptation ${ }^{14}$.

\section{Population and samples}

In $\mathrm{RN}$, the adherence to PMAQ-AB incurred to 370 Basic Health Units (BHU) and to 412 Primary Care Teams (PCT), equivalent to $34.1 \%$ of $\mathrm{BHU}$ and $43.87 \%$ participation of PCT in the state wide. The source population from such study consisted in 1,650 BHU adult users, of which only 119 met the admittance criteria: to be bearer of diabetes mellitus as diagnosed by a doctor. There hadn't been any exclusion criteria for such sample composition, since the sample was casually performed, among those members present at the BHU at the time of the interview ${ }^{15}$.

\section{Data collection}

The users were interviewed in the Basic Health Units (BHU), as previously performed by a pioneer study for instrument validation. Upon this perspective, the data were collected by trained interviewers and capable for such task, via surveys in electronic format, available on tablets. Such surveys, by all means, had been properly prepared by renowned research institutes in Brazil, with the approval of Ministry of Health. The application was validated by a digital tool, following the date of confirmation protocol, the correspondence between geographic coordinates and the site of application, time of application and filling in all questions, the percentage of "do not know" and "no response".

\section{Variables}

In order to enhance the knowledge of the sample and to achieve the proposed objective, the following variables were considered: socio-demographic variables (age; sex; color or race; literacy; years studied; family income); working days of the unit on a weekly basis, as well as the operation to meet the need of users; turnaround time for the user to be heard; sufficient time for the user to talk about their problems or concerns with the doctor; the feet care examination by the doctor in the last six months; the proper modus of acquisition of the 
medication for diabetes; evaluation of the care taken by the health team; assigned note for the satisfaction upon the care received in the unit.

\section{Analyzed Data}

The data were analyzed by descriptive measurements, pursuant absolute frequencies and percentages for qualitative variables, and quantitative variables were described by average figures and standard deviation. For the sake of processing and the data analysis, it was used the IBM SPSS program for Windows, version 17.0.

\section{Ethical Aspects}

The multicenter study was approved by the Research Committee on Ethics (RCE) of the Federal University of Rio Grande do Sul by the number 21904 on March $13^{\text {th }}, 2012$, and in line with the Resolution No. 196/96 of the National Health Council (NHC).

\section{RESULTS}

Out of 1,650 adult users surveyed in this study, only 119 (7.21\%) patients were diabetes mellitus bearers, once diagnosed by the doctor. From these users, the vast majority were female, of nonwhite ethnicity (Afro-Americans, yellow, brown, indigenous, etc.) and with an average age of approximately 53 years (as Table 1).

Additionally, most of the users had less than four years of study, resulting in a large percentage of individuals who are illiterate or could barely sign their names. As for the family income, most of them had an income of up to three minimum wages. 
Table 1 - Socio-demographic aspects of the 119 participants of the study.

\begin{tabular}{|c|c|c|c|c|}
\hline Variables & $\mathbf{n}$ & $\%$ & Average & Standard Deviation \\
\hline \multicolumn{5}{|l|}{ Gender } \\
\hline Male & 21 & 17,6 & & \\
\hline Female & 98 & 82,4 & & \\
\hline \multicolumn{5}{|l|}{ Age (years old) } \\
\hline 20 to 30 & 6 & 5 & & \\
\hline 31 to 40 & 16 & 13,5 & & \\
\hline 41 to 50 & 26 & 21,9 & 53 & 14,77 \\
\hline 51 to 60 & 27 & 22,7 & & \\
\hline 61 to 70 & 27 & 22,7 & & \\
\hline$>70$ & 14 & 11,7 & & \\
\hline Do not know / no response & 3 & 2,5 & & \\
\hline \multicolumn{5}{|l|}{ Color/Ethnicity } \\
\hline White & 46 & 38,7 & & \\
\hline Nonwhite & 73 & 61,3 & & \\
\hline \multicolumn{5}{|l|}{ Literacy } \\
\hline Yes & 70 & 58,8 & & \\
\hline No & 20 & 16,8 & & \\
\hline Only sign the name & 29 & 24,4 & & \\
\hline \multicolumn{5}{|l|}{ Years of study } \\
\hline Never attended & 19 & 16 & & \\
\hline Attended until 4 years & 37 & 31,1 & & \\
\hline Attended from 5 to 8 years & 13 & 11 & & \\
\hline Attended 9 years or more & 2 & 1,6 & & \\
\hline Do not know / no response & 48 & 40,3 & & \\
\hline \multicolumn{5}{|l|}{ Family Income } \\
\hline No more than 1 min. wage ${ }^{* *}$ & 45 & 37,8 & & \\
\hline 1,01 to $<3,00 \mathrm{~min}$. wage & 52 & 43,7 & & \\
\hline$>3,00$ min. wage & 4 & 3,4 & & \\
\hline Do not know / no response & 18 & 15,1 & & \\
\hline
\end{tabular}

NOTE: *The no nwhite ethnicity is equivalent to : black, yellow, mulatto or mestizzo, indigeno us or other; ${ }^{*} 1 \mathrm{~min}$. Wage at the time of the interviw is equivalent to $R \$ 622,00$.

Subtitles: n: sample; \% percentage

When the participants were surveyed regarding the working hours of the health unit, 100 participants (84\%) claimed the unit worked properly for five days a weekand $16 \%$ of them stated that the unit did not work five days a week or did not know/ no response. Such availability of the evaluated units was sufficient to comply with the needs of $98(82 \%)$ of the participants. The rest of the surveyed indicated not to be enough or did not know / no response. 
In regard to the waiting timeframe for the patients from their arrival until the time they could actually talk to the professional, there were many different answers (except for the 40 participants who did not know, or gave answers that did not apply). Thus, for the sake of the proper analysis, the waiting timeframe were divided into equal ranges of 30 minutes each. Thus, it was observed that most of the participants were attended in less than thirty minutes. If we exclude from the analysis the 40 invalid responses, we may say, then, most of the patients were attended in less than half an hour. The average timeframe for such service was approximately 31 minutes, with a standard deviation of 38.21 .

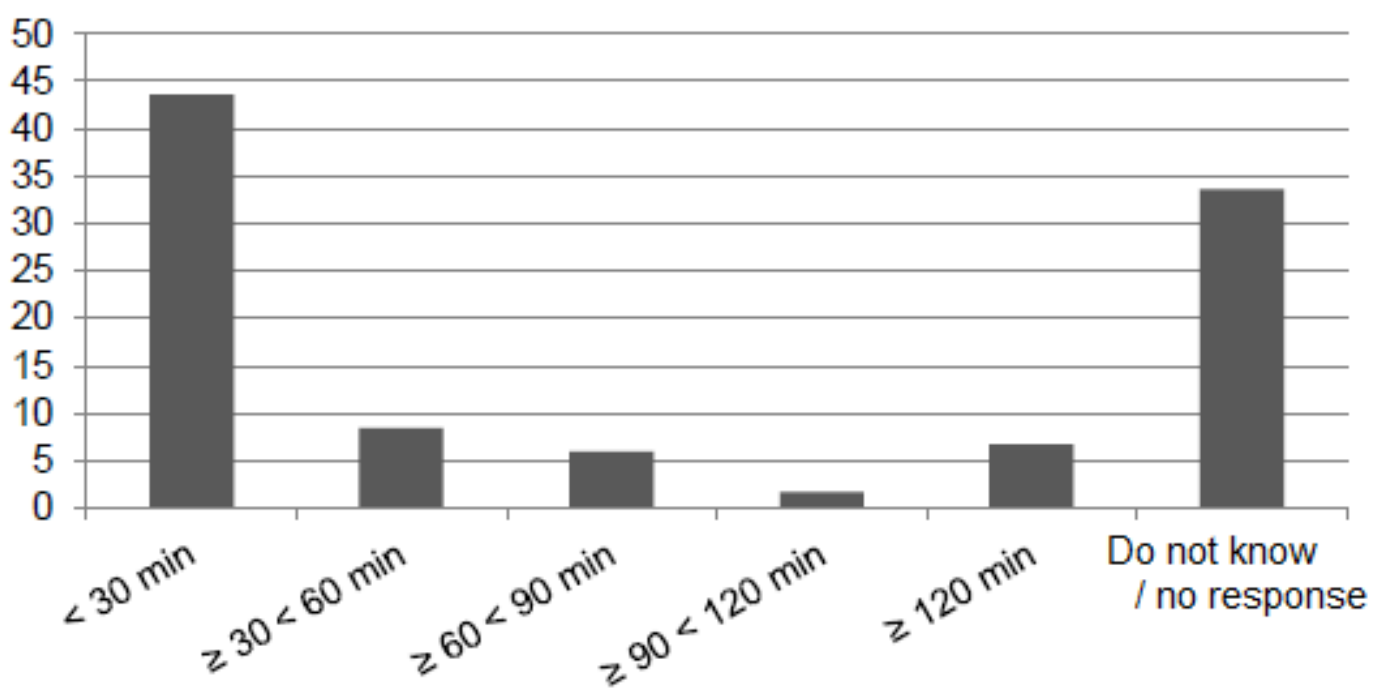

Figure 1 - Waiting timeframe to argue with a health professional regarding the issue until the arrival.

In reference with the appoitment turnaround time to be or not to be enough for the bearer in order to talk about their problems or concerns with the doctor, 106 surveyed $(89.1 \%)$ said that this time is enough. The rest said that is not enough, that has never been attended by such professional or do not know / no response.

As for the vast majority the time attended has been enough with the doctor, the surveyed (82.4\%) reported not to have their feet examined by the health professional in the last six months (Figure 2), and 75 (63\%) bearers also had not even received any guidance about the proper feet care recommended within the last six months. The other $37 \%$ were properly guided (there were no invalid responses). 


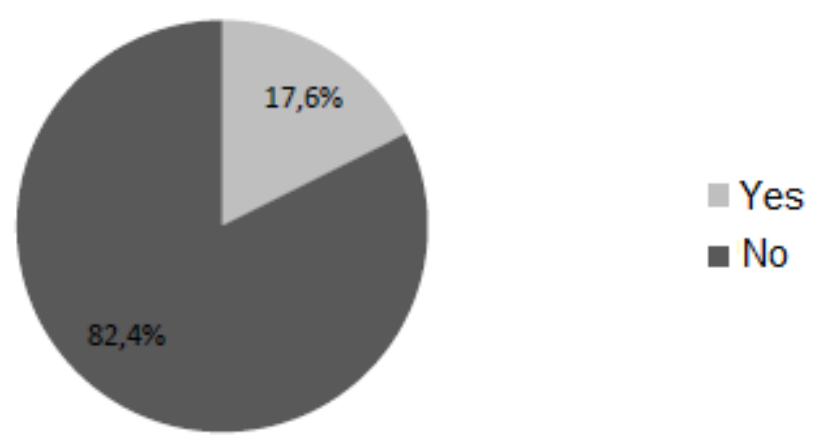

Figure 2 - Surveyed patients who had their feet duly examined.

In regard to pharmacological care of the disease, 92 (77.3\%) bearers reported having access to free medicine. Only five patients $(4.2 \%)$ had to pay for the medication. 22 participants (18.5\%) reported having access to medication by other means not specified or furnished answers which was not applicable.

In the opinion of the participants, the care rendered by the health team was positively evaluated by $78.2 \%$ of surveyed $(20.2 \%$ considered very good and $58 \%$ considered good). Only four of them (3.3\%) had considered the care bad or very bad. 22 participants (18.5\%) considered regular care.

Finally, it was requested to the surveyed to assign a grade from zero to ten in evidencing their satisfaction with the care received in the unit; most of them had assigned a higher score rather or equal to eight. Only a minuscule portion of bearers assigned a lower score than five. The average grades assigned was 8.35, with a standard deviation of 2.22 (Graphic 3).

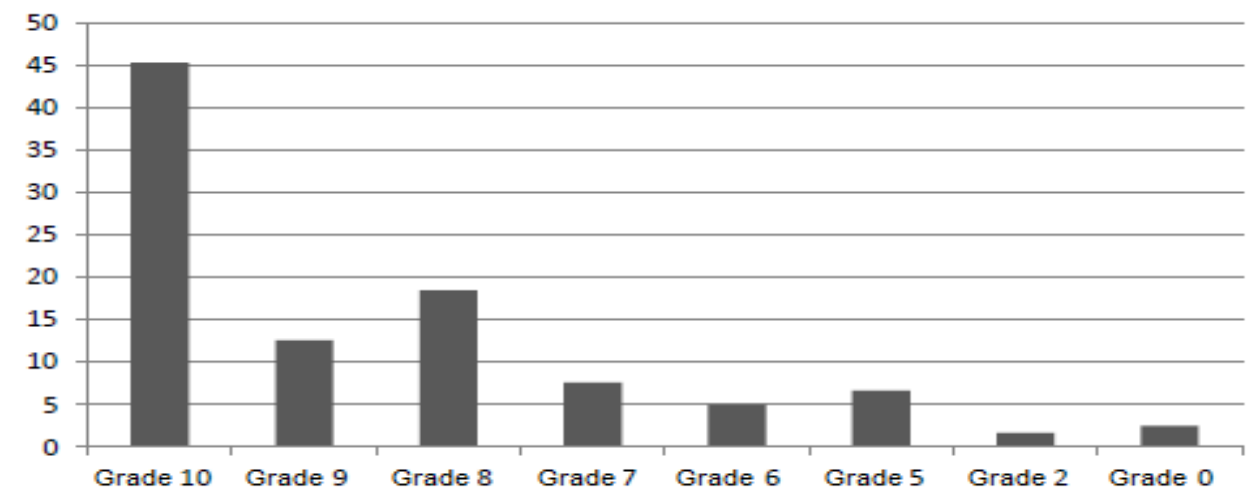

Figure 3 - Assigned grade towards satisfaction with the care rendered at the unit. 


\section{DISCUSSION}

It was observed in this essay, the estimate of diabetic patients is above the estimate ratio for Brazil (5.9\%) in 2013, according to the International Diabetes Federation ${ }^{16}$. On the one hand, when comparing the estimate of diabetes in Rio Grande do Norte (7.1\%) across the Northeast ratio (10.7\%), it is clear that Rio Grande do Norte has a lower ratio ${ }^{17}$.

Regarding the socio-demographic data, the interviewed patients indicate female as the predominant profile, adults, low education level and having a low family income. In this study, the diabetic women ratio was significantly higher than men, as in other studies ${ }^{18-19}$. It is taken into the account that the lower ratio of diabetes in men, as a matter of fact, is carried out of this certain stream line to be connected to the work or given into a lower priority to those users. Regarding the age, studies have indicated that the elderly ( $>65$ years) present a higher ratio of diabetes ${ }^{19}$, while the under-25s individuals indicate the lowest ratio. Such findings haven't been fully verified in this study, once the most common ratio ranks upon the age between 51 and 70, while less common age to remain below the 30 years old. Once the diabetes to be taken as a multifactorial disease associated with poor quality living habits, such as physical inactivity and improper $\operatorname{diet}^{9}$, the fact of which there are a considerable number of individuals below 65 years with the given disease may indeed be associated with the current lifestyle society trend, as becoming increasingly harmful to health, triggering such diseases at earlier ages.

As per the literacy rate, it was found that most of the diabetic users have a low educational level, as evidenced by the low literacy rate, and especially the low number of years of study. Such information was reported in other populational studies $^{18-19}$. In association with the income, it was shown the diabetes rate to be higher in the population whose family was up to three minimum wages, in other words, upon low family income. This result is similar to the oneas seen in another Brazilian survey ${ }^{12}$, let alone discrepancies as found by Passos et $\mathrm{al}^{18}$. There is a possibility of these data (low educational level and low monthly family income) not to be directly related to diabetes, but to match the patient profile which 
sources the public health services, since there is a certain tendency in our country that people from higher economic level will eventually seek private services. The low literacy rate can be a finding as much precise as influenced by the difficulties imposed by the low revenue in contrary to the quality education.

Regarding the access to health services, a positive finding in the study was the fulfillment of the number of days set by the Ministry of Health for working hours of the basic units ${ }^{20}$ and, for the majority, the number of days to be adequate towards their needs.

In relation to the waiting timeframe, the Ministry of Health brochure regarding "Attendance of Health Production Practices"21 says that this type of service requires the determination of service agility. Furthermore, as the "Schedule of Rights from the Health Users"22, also inured to Ministry of Health, entitles the citizen to have an agile treatment, an appropriate technology and a trained multidisciplinary team, so the health care to suit the scenario in order to avoid delays in queues. This waiting timeframe to be attended was one of the aspects which had the lowest level of satisfaction by users in the Worldwide Health Survey ${ }^{23}$. Thus, we can say that such variable was leaning forward very positively on this study, once the participants were treated on an average of about half an hour. The fact that the appointment turnaround time with the doctor is considered as sufficient for most users is a positive finding, although this timeframe has not been used to feet examination of the bearers patients neither to alert them about proper feet care.

Noteworthy both the compliance with the recommended operating hours and the establishment of an appropriate attention to be key features, it must be obeyed by the $\mathrm{BHU}$ in order to be entitled in $\mathrm{PMAQ}-\mathrm{AB}^{14}$. With this in mind it leads us to conclude that the teams that did not fit or that no longer obey such rules were not part of the study, enticing as an important bias.

However, it was in relation to the physical examination in which the most alarming figures were verified. Most patients did not have the feet duly examined as carried out in the recent months. This fact was evidenced in both studies in the city of Francisco Morato ${ }^{12}$, in which almost $90 \%$ of bearers had an incomplete or poor physical examination, and the evaluation of diabetic patients in Ribeirao Preto $^{24}$, in which the records had systematic errors in the physical examination, 
with only $15 \%$ of record on examination of diabetic feet and even fewer in respect to the examination of optical exam (4.3\%).

The Brazilian Diabetes Society ${ }^{25}$ recommends, at least a thoroughly feet evaluation on a yearly basis (with the use of monofilament and at least one further test for protective sensation loss). It also recommends the identification of the possibility of self-care and proper advice in each every opportunity, a fact which was not observed as something to be sufficiently achieved in this study as well. Taking into accountthe probability of $25 \%$ development of diabetic foot throughout the lifetime for those patients ${ }^{26}$ and about $20 \%$ of hospitalizations related to diabetes to remain due to problems in the lower limbs ${ }^{27}$, it can be dimensioned the huge gap of the quality of service faced by diabetic users.

Considering the physical examination of the diabetic foot to bean assignment of doctors and nurses (mostly medical inured) ${ }^{25}$, it can be assumed these professionals are being negligent towards the proper care of patients, not to mention the size of the morbidity which can be caused from the lack of feet examination. In terms of guidance regarding the feet, the same negligence can be pointed out to all BHU wise, from medical professional to the community health agent.

In the study, it was also evidenced the use of drugs to control the disease as being part of most of the patients, as half of them manage to get the medicine in the health unit. The receipt of medicine at the same health station is directly involved with better resolution of the disease ${ }^{28}$ not to mention the free receipt of it, from one way to the other, it impacts in a higher attendance of a second time appointment in the same unit ${ }^{29}$. As otherwise defined in Francisco Morato's essay $^{12}$, of which more than half of patients didn't use to receive the medicine in the unit and $63 \%$ reported a monthly disbursement of such drug, as only a small portion of the users surveyed in the state health units need to pay for the medicine. Thus, it was noticed a wide free access to pharmacotherapy, nonetheless, its acquisition (as held at the health unit) still needs to be improved.

Regarding the bearers assessment, as of the offered care rendered by the health professionals, the vast majority evaluated very well such subject. Similar results were found in the study of Santiago et $\mathrm{al}^{30}$, in the evaluation of the performance of the professionals it also indicated good levels of satisfaction. 
Finally, in connection to the assigned grade towards user satisfaction upon the rendered care, the great amount of eight, nine and ten graders sets the level to a very high standard of satisfaction upon the surveyed participants. The results corroborate as the insights once observed in another study ${ }^{30}$, where the level of patient's satisfaction, in general, was also considerably high. These results constitute prerogative of which probably encores the situation of primary care as shown to significant grounds of progress lately. Another possibility is that the satisfaction evaluation to peak in those mentioned high levels are due to the alleged lack of knowledge of users about their rights and end up being satisfied with a situation which is unequal from what it should be offered.

\section{CONCLUSION}

The socio-demographic profile of the surveyed diabetic patients from Rio Grande do Norte within the participating units as per PMAQ-AB reveals a predominance of women aged from 51-70 years old with low literacy rate and low family monthly income. Despite there was no significant difference in the prevalence of diabetes among men and women in Brazil, the lower ratio of male may incur to the higher connection these man are with labor activities. Therefore, it is inured that, in the State wise, perhaps the working hours of the basic units in different times in order to cope almost exclusively to the required margin of such this population, increasing the male access.

It was observed the access, not only to both the health unit as the free medication handover, the acceptance and satisfaction of the general bearer with the proper care offered to them were highly regarded in terms of the aspects of the study, although there are some important biases which should be considered, such as the fact of only a portion of the study units complies with the remaining criteria in PMAQ-AB as well as the literacy rate of the participants (possibly interfering with SUS satisfaction analysis). However, there is a need for enhancements regarding physical examination, specifically in respect of feet examination. Regarding the last issue, most of diabetic patients were not even advised of the need for special attention to the feet neither of its possible implications, thus furnishing evidences to a failure in the process of promotion 
and to the health prevention. It is suggested, therefore, a considerable dedication of the $\mathrm{BHU}$ in relation to compliance with such items, especially from doctors and nurses.

Another relevant aspect towards health promotion and prevention could be related to a massive investment in public policies for the education of the population, which may trigger higher levels of general education and consequent better comprehension of the disease and its complications.

Finally, it may be highlighted the importance of such studies in order of evaluating the quality of service, enabling the recognition of the positive points, with a view to its perpetuation, and linked weaknesses, with the purpose of drafting new proposals to serve as a medicine to the difficulties and also to improve the assistance offered to the patients in general. Valuable to note, the number of surveyed patients represents only a small portion on the total number of diabetics who render use of public services in the State, reinforcing the need for further research with larger population coverage, in order to increase knowledge about the offered attention to the population with diabetes.

\section{REFERENCES}

1. Alwan A, MacLean DR, Riley LM, D'Espaignet ET, Mathers CD, Stevens GA, Bettcher D. Monitoring and surveillance of chronic non-communicable diseases: Progress and capacity in high-burden countries. Lancet. 2010; 376 (9755): $1861-68$.

2. World Health Organization (OMS). Global status report on noncommunicable diseases. Geneva: WHO; 2011.

3. Ministry of Health (Brazil). Secretary of Health Surveillance, Health Department. Situation Analysis of Pan American Health Organization / World Health Organization: The Control and Prevention of Chronic NonCommunicable Diseases: NCD: in the context of the single Brazilian health system. Brasilia: Ministry of Health; 2005. 6 p.

4. Ministry of Health (Brazil). Secretary of Health Surveillance, Health Department. Situation Analysis of Pan American Health Organization / World Health Organization: The Control and Prevention of Chronic NonCommunicable Diseases: NCD: in the context of the single Brazilian health system. Brasilia: Ministry of Health; 2011-2022. 8-9 p. 
5. King H, Aubert RE, Herman WH. Global Burden of Diabetes, 1995-2025. Prevalence, numerical estimates and projections. Diabetes Care. 1998; 21(9):1414-31.

6. Malerbi DA, Franco, LJ. Multicenter study of the prevalence of diabetes mellitus and impaired glucose tolerance in the urban Brazilian population aged 30-69 years.The Brazilian Corporative Group on the Study of Diabetes Prevalence. Diabetes Care. 1992; 15(11):1509-16.

7. Ministério da Saúde (BR). DATASUS. Informações de Saúde. Mortalidade, 2011. [Acesso em 8 jul. 2015]. Disponível em: http://www.datasus.gov.br.

8. American Diabetes Association. Diagnosis and Classification of Diabetes Mellitus. Diabetes Care. 2012; 35(Supl1).S64-71.

9. Assunção MCF, Santos IS, Costa JSD. Avaliação do processo da atenção médica: adequação do tratamento de pacientes com diabetes mellitus, Pelotas, Rio Grande do Sul, Brasil. Cad Saúde Pública. 2002; 18(1):20511.

10. Ministério da Saúde (BR). Secretaria de Atenção à Saúde, Departamento de Atenção à Saúde. Cadernos de Atenção Básica nำ16. Diabetes Mellitus: Normas e Manuais Técnicos. Brasília: Ministério da Saúde; 2006.10 p.

11. Vinicor F. The public health burden of Diabetes and the reality of limits. Diabetes Care. 1998; 21 (Suppl. 3): C15-8.

12. Paiva DCP, Bersusa AAS, Escuder MML. Avaliação da assistência ao paciente com diabetes e/ou hipertensão pelo Programa Saúde da Família do Município de Francisco Morato, São Paulo, Brasil. Cad Saúde Pública. 2006; 22 (2): 377-385.

13. Bersusa AAS, Pascalichio AE, Pessoto UC, Escuder MML. Acesso a serviços de saúde na baixada santistade pessoas portadoras de hipertensão arterial e/ou diabetes. Rev Bras Epidemiol. 2010; 13:513-22.

14. Ministério da Saúde (BR). Programa Nacional de Melhoria do Acesso e da Qualidade da Atenção Básica (PMAQ): Manual instrutivo. Brasília: Ministério da Saúde, 2012. [Acesso em 8 jul. 2015]. Disponível em: http://dab.saude.gov.br/portaldab/ape_pmaq.php?conteudo=1_ciclo.

15. Ministério da Saúde (BR). Banco de dados da avaliação externa do programa de melhoria do acesso e da qualidade da atenção básica. Brasília: Ministério da Saúde, 2013. [Acesso em 13 jun 2015]. Disponível em:

http://dab.saude.gov.br/portaldab/ape_pmaq.php?conteudo=microdados.

16. Internacional Diabetes Federation (IDF). Diabetes atlas. 5 ed.Belgium: Internacional Diabetes Federation, 2013. [Acesso em 01 jul. 2015]. Disponível em: https://www.idf.org/diabetesatlas.

17. Ministério da Saúde (BR). Indicadores de fatores de risco e proteção: Prevalência de diabetes mellitus no Nordeste no ano de 2012. Brasília: 
Ministério da Saúde, 2012. [Acesso em 08 ago. 2015]. Disponível em: http://tabnet.datasus.gov.br/cgi/dh.exe?idb2012/g01.def.

18. Passos VMA, Barreto SM, Diniz LM, Lima-Costa MF. Type 2 diabetes: Prevalence and associated factors in a brazilian community - the bambuí health and aging study. Sao Paulo Med J. 2005; 123(2): 66-71.

19. Ministério da Saúde (BR). Caderno de atenção básica, n. 36: Estratégias para o cuidado da pessoa com doença crônica - diabetes mellitus. Brasilia: Ministério da Saúde, 2013. [Acesso em 16 jul. 2015]. Disponível em:

http://bvsms.saude.gov.br/bvs/publicacoes/estrategias_cuidado_pessoa_ diabetes_mellitus_cab36.pdf.

20. Ministério da Saúde (BR). Política nacional de atenção básica (Pnab). Brasilia: Ministério da Saúde, 2012. [Acesso em 15 jul. 2015]. Disponível em: http://189.28.128.100/dab/docs/publicacoes/geral/pnab.pdf.

21. Ministério da Saúde (BR), Secretaria de Atenção à Saúde, Núcleo Técnico da Política Nacional de Humanização. Acolhimento nas práticas de produção de saúde. Brasília: Ministério da Saúde; 2010. 2 ed. 6p. [Acesso em 4 ago. 2015]. Disponível em: http://bvsms.saude.gov.br/bvs/publicacoes/acolhimento_praticas_produc ao_saude.pdf.

22. Ministério da Saúde (BR). Conselho Nacional de Saúde. Carta dos direitos dos usuários da saúde. Brasília: Ministério da Saúde; 2011. 7p. [Acesso em 6 ago. 2015]. Disponível em: http://www.use.ufscar.br/direitos-edeveres-dos-usuarios/carta-direitos-usuarios.

23. Szwarcwald CL, Leal MC, Gouveia GC, Souza WV. Desigualdades socioeconômicas em saúde no Brasil: resultados da Pesquisa Mundial de Saúde, 2003. Rev Bras Saude Mater Infant. 2005; 5 (Suppl 1): s11-s22.

24. Silva ASB, Santos MA, Teixeira CRS, Damasceno MMC, Camilo J, Zanetti ML. Avaliação da atenção em diabetes mellitus em uma unidade básica distrital de saúde. Texto contexto - enferm. 2011; 20 (3): 512-518.

25. Sociedade Barsileira de Diabetes (SBD). Diretrizes da Sociedade Brasileira de Diabetes 2014-2015. São Paulo; 2015. [Acesso em 18 ago. 2015]. Disponível em: http://www.diabetes.org.br/images/2015/arearestrita/diretrizes-sbd-2015.pdf.

26. Boulton AJM, Armstrong DG, Albert SF, Frykberg RG, Hellman R, Sue Kirkman M, et al. Comprehensive fool examination and risk assessment: $A$ report of the task force of the foot care interest group of the American diabetes association, with endorsement by the American association of clinical endocrinologists. Phys Ther. 2008; 88 (11):1437-1443.

27. Grupo de trabalho internacional sobre pé diabético. Consenso internacional sobre pé diabético. Brasília: Secretaria de Estado de Saúde do Distrito Federal; 2001. [Acesso em 14 ago. 2015]. Disponível em: http://189.28.128.100/dab/docs/publicacoes/geral/conce_inter_pediabetic o.pdf. 
28. Halal IS, Sparrenberger F, Bertoni AM, Ciacomet C, Seibel CE, Lahude FM, et al. Quality evaluation of primary health care in an urban area of southern Brazil. Rev Saúde Pública. 1994; 28 (2): 131-136.

29. Turrini RNT. Percepção dos usuários sobre a resolutividade e a satisfação pelos serviços de saúde na região sudoeste da Grande São Paulo. São Paulo. Tese [Doutorado em Saúde Pública] - Escola de Enfermagem, Universidade de São Paulo; 2001.

30. Santiago RF, Mendes ACG, Miranda GMD, Duarte PO, Furtado BMASM, Souza WV. Qualidade do atendimento nas Unidades de Saúde da Família no município de Recife: a percepção dos usuários. Ciênc Saúde Coletiva. 2013; 18 (1): 35-44. 